ISSN: 0213-2060

DOI: https://doi.org/10.14201/shhme20203824373

\title{
THE ETERNAL PEASANT AND THE TIMELESS VILLAGE. ARCHAEOLOGY AND IDEOLOGIES OF THE PAST
}

\author{
El campesino eterno y la aldea atemporal. Arqueología e ideologías del pasado
}

\author{
Rainer SCHREG \\ Otto-Friedrich-Universität Bamberg Lehrstuhl für Archäologie des Mittelalters und der Neuzeit. Institut für \\ Archäologische Wissenschaften, Denkmalwissenschaften und Kunstgeschichte. Am Kranen 14. 96047 BAMBERG. \\ C.e.: rainer.schreg@uni-bamberg.de
}

Recibido: 2020-06-16

Revisado: 2020-09-28

Aceptado: $2020-10-26$

ABSTRACT: The perspectives on the medieval village and on the historical role of peasants have changed throughout the history of research. Traditional views on history saw rural life as unchangeable and therefore presumed that villages were rooted in the migration period. Modern research recognised the formation of the medieval village as a complex longterm process that, depending on the region, culminated in the $11^{\text {th }}-13^{\text {th }}$ century. This paper takes a closer look at the situation in southwestern Germany, analysing research history on the one hand and selected episodes of medieval rural history on the other. The paper suggests that due to traditional views on the structure of history, peasants' agency has been undervalued.

Keywords: Village formation; Southern Germany; open field system; environmental history.

RESUMEN: Las perspectivas sobre la aldea medieval y sobre el papel histórico de los campesinos han cambiado a lo largo de la historia de la investigación. Las opiniones tradicionales hechas desde la historia consideraban que la vida rural era inmutable y, por tanto, presumían que las aldeas tenían sus raíces en el periodo de las migraciones. La investigación moderna reconoció la formación de la aldea medieval como un proceso complejo y de larga duración que culminó en los siglos XI y XIII, dependiendo de cada región. Este artículo examina más de cerca la situación en el suroeste de Alemania, analizando la historia de la investigación, por un lado, y ciertos episodios seleccionados de la historia rural medieval, por el otro. Este trabajo sugiere que, debido a los puntos de vista tradicionales sobre la estructura de la historia, la agencia de los campesinos ha sido infravalorada. 
Palabras clave: Formación de las aldeas; Alemania meridional; Sistema de campos abiertos; Historia medioambiental.

SUMMARY: 0 Introduction. 1 Archaeological ideas about village history. 2 Ideologies of the past. 3 A discrepancy between the archaeological and the written record. 4 Formation processes of the archaeological and historical record. 5 Peasants' agency in settlement change of Southern Germany. 6 The early medieval shifting settlements. 7 The introduction of a regulated open field system and village formation. 8 Pioneers and people without a voice: medieval colonisation processes. $914^{\text {th }}$ century crisis. 10 Peasants or lords? 11 Castles and manors. 12 Local rural societies. 13 Conclusion. 14 References.

\section{INTRODUCTION}

Once upon a time, there was an Alemannic count leading a hundred warriors and their families into the territory of the Roman Empire (fig. 1). He chose a nice piece of land, founded a village there. Ever since, his descendants lived as farmers and were patronised (or suppressed - depending on your conservative or Marxist worldview) by their aristocracy, who derived themselves in direct line from the migration period rulers. There were many of these noblemen and therefore many villages were founded this way. Their names remember the founders and their clans. The village Renningen refers to the clan of Rando, Waiblingen to the one of Wibilo, for example. After some generations, the villagers became baptized, built a church in the centre of their village, and formed a parish. In the perennial alteration of sowing and yielding, peasant life went on without any major changes, people preserved their tribal identity expressed by the architecture of their houses and by their traditional costume.

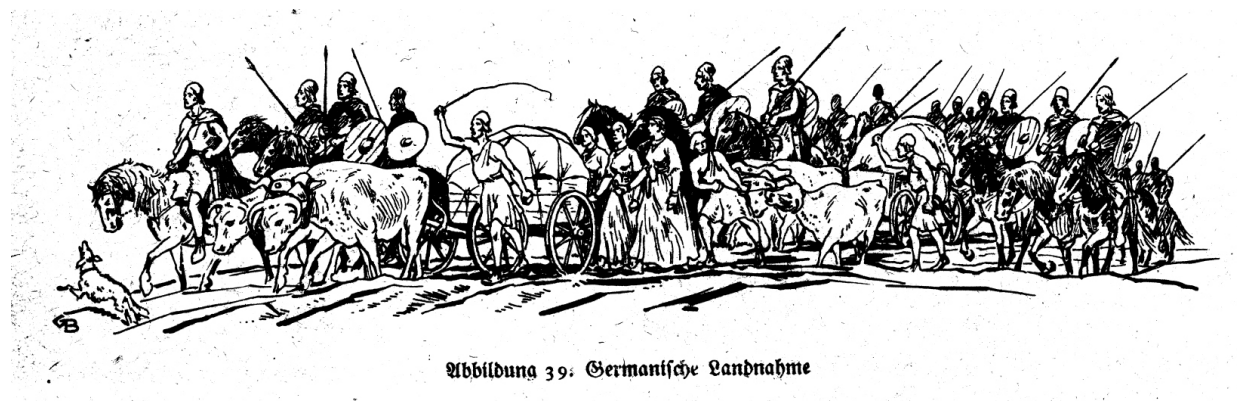

Figure 1. Migration period.

For sure, this is a somewhat overstressed and simplified depiction, but at its core, in the first half of the $20^{\text {th }}$ century this was the generally valid idea about the history of the medieval village in southwest Germany ${ }^{1}$.

1 Weller (1938). 
This traditional view is based on the narrative of continuity, leadership, and topdown organisation. Overall the narrative of the primordial village shows the main characteristics of historicism: (1) the individuality of every historical situation; (2) the high importance of the state, understood as the aim of history; (3) the high mportance of the nation, understood as a community determining history; (4) the relativity of values; (5) a specific methodology that aims to understand rather than to explain historical situations; and (6) a chronological narrative of events ${ }^{2}$. These ideas go back to philosophers like Georg Wilhelm Friedrich Hegel (1770-1831), Leopold von Ranke (1795-1886), Johann Gustav Droysen (1808-1884) and finally Ernst Bernheim (1850-1942). In this framework, agency is with the genius (Hegel) or at least with powerful individuals as politicians, generals, or rulers. However, it denies peasants' agency. Historicism was deeply rooted in German culture and was hence also an important background concept in medieval rural archaeology.

\section{Archaeological ideas about Village history}

Medieval archaeology in Germany emerged from heritage management and rescue projects on the one hand, and an interest in representative monuments on the other hand. In the 1920s, the Römisch-Germanische Centralmuseum at Mayence was in charge of the management of the archaeological heritage in the Hessian provinces Rheinhessen and Starkenburg. Excavations at the palatium of Ingelheim, the castle of Dreieichenhain and Lorsch abbey, as well as of some churches represent a first stage of excavations run by professional archaeologists ${ }^{3}$. However, they focused on monuments of power, whereas the first excavations of rural settlements in the 1920s and 1930s were pure rescue excavations, often by mistake, as researchers originally hoped to find prehistoric sites. This was the time when what can be called a 'modern settlement archaeology' began. Already before this development, there had been a 'settlement archaeology', represented by Gustaf Kossinna, interested not in settlements though but ethnic territories and migrations. He presumed that «race» determined the people and their culture, resulting in long-lasting cultural traditions and stability through time ${ }^{4}$. This research tradition became an important element of Nationalsocialist ideology. It represented a legitimation for the «Führerprinzip» («leader principle») who lead the «Volkskörper» (population defined by their common blood and race). The village was therefore seen as the natural form of Germanic settlement. This idea directly influenced NS-politics in the territories of Eastern Europe occupied by German forces during WW II. The "Generalplan Ost» planned the founding of villages settled with SS-soldier-peasants («Wehrbauern»). All over Germany newly established model villages promoted village life and the conservative ideal of peasants' families.

\footnotetext{
Oexle, Rüsen (1996).

Schreg (2020).

Kossinna (1911), p. 3.
} 
This ideological and/or political paradigm resulted in the neglect of archaeological evidence indicating that villages might have been formed at a later stage than traditionally assumed. In southwest Germany, Hermann Stoll and Walter Veeck, both mainly interested in Merovingian burial sites, found already in the 1930s clear indication for a more complex development of villages. However, they both did not draw any further conclusions from their own research and remained convinced, that the main Merovingian settlements must have been at the location of the younger villages. Herman Stoll excavated a huge Merovingian burial site close to Hailfingen and also discovered an early medieval settlement close by. In his conclusion he even stated a gradual formation of the village and postulated a social transformation from kinships to early medieval village communes 5 . Walter Veeck suggested a at first dispersed settlement structure and only later village concentration, because he observed the existence of more than one Merovingian cemetery close to the younger villages ${ }^{6}$. Nevertheless, the continuity of villages was not taken into question. State archaeologist Oscar Paret even declared that the modern streets of Untertürkheim close to Stuttgart reflected the street pattern from the time when the village was founded in the early Middle Ages ${ }^{7}$.

A very illustrative example for the idea of the unchanging village structure represents the model of an early Alemannic dwelling by the reconstruction department (Modellwerkstatt) of the «Reichsbund für deutsche Vorzeit». In 1936, they simply took an early modern farmhouse from pre-alpine Upper Swabia as a template for the Alemannic structure, bridging more than 1000 years (fig. 2) ${ }^{8}$.
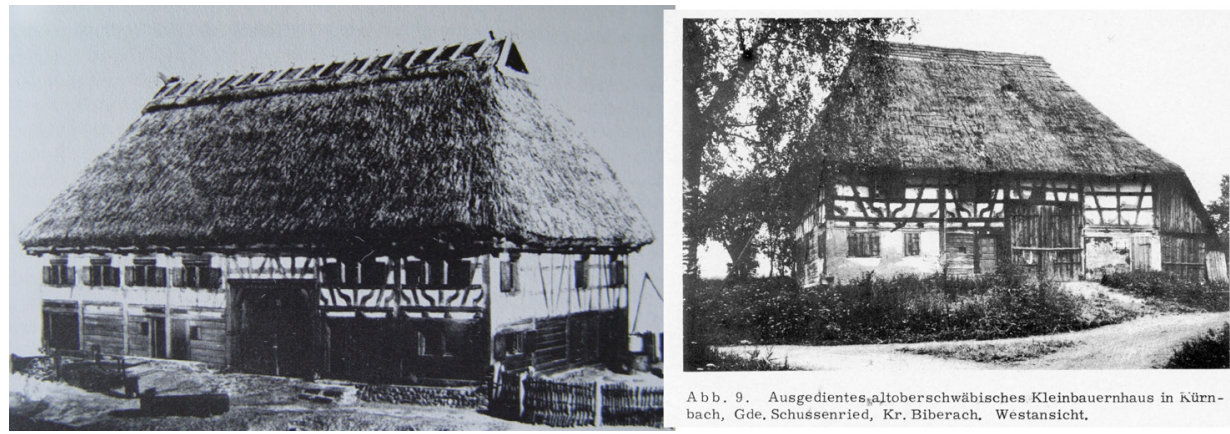

FIGURE 2. Left: reconstruction of an early Alamannic house by the Reichsbund für Deutsche Vorgeschichte 1937 (Schröder 1997); right: Lipp house at Kürnbach dating to $17^{\text {th }} c$.

Of great importance for the knowledge of medieval settlements became the excavations at Neuwied-Gladbach in 1937/38, where it was possible for the first time to

5 Stoll (1939), p. 40.

6 Veeck (1931), pp. 117-122.

Paret (1937), 90f.

Schröder (1997), p. 74 Abb. 8. 
reconstruct houses based on real archaeological evidence'. The discovery of pit houses and house construction types with wooden posts proved that early medieval houses were different from known preserved traditional rural buildings. Nevertheless, various researchers tried to substantiate continuous traditions in architecture from the migration period to modern times. Late medieval deserted settlements found a broad interest since the $19^{\text {th }}$ century, but they were also not registered as an indication of discontinuity. Still in the 1950s geographer Otto Schlüter understood the development of central European cultural landscape as a progressive clearance and colonisation of land ${ }^{10}$.

Despite quite clear evidence for major transformations in the rural landscapes, it still took several decades after WW II before archaeologists paid adequate attention to changes of the medieval rural landscape. It appears to me that this was mainly due to deficits in theory in the new field of medieval archaeology. Still in the late 1980s a famous introductory textbook by Günter Fehring, a prominent German medieval archaeologist, who is highly commendable for the establishment of the discipline, omitted theoretical approaches, as they were «antihistorical»" This shows that it was taken for granted that archaeology is part of history. But as there was no deeper reflection on what 'history' could mean for archaeologists it was not possible to gain innovative impulses and to develop advanced archaeological research questions. When looking at some texts by prehistorians we see that they depended on the ideas of historicism. The same seems true for medieval archaeologists, but because of a lack of theoretical papers, we can only conclude this from their ways of interpretation and their research topics. As still in recent decades some colleagues understand an ethnic interpretation of archaeological finds as a major task and a precondition for archaeology as a subdiscipline of history, we can take this as a strong evidence of a historistic understanding of history. Other concepts like «archaeology as anthropology», fundamental for the New Archaeology of the 1960s and 70 s, were refused and approaches like the one of French Annales were seldom reflected ${ }^{12}$.

In consequence, research interests focused mainly on rural material culture, including houses, churches, and burial sites. To a certain degree, research was descriptive and empirical, but not analytical. Archaeologists did not develop their own interpretations of past changes, but rather illustrated given knowledge or focused on aspects of rural daily life. Archaeologists dealt only with settlement processes visible in the written sources, such as the late medieval urbanisation or the late medieval period of settlement desertion $^{13}$. By political reasons more interest in settlement change and the historical role of the peasants was present in the former GDR, where archaeologists paid closer attention to the economic background and living conditions and therefore started the attempt to conduct large scale comparative studies ${ }^{14}$. The transition between different stages of production organisation as well as a focus on the Slavic period were politically favoured

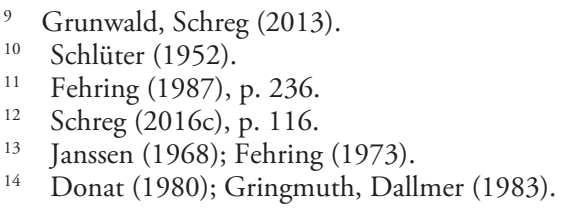


topics. In contrast to the situation in Southern Germany, many villages in Eastern Germany show a regular form. Researchers thought for a long time that these latter villages must have been the result of a planned colonisation. Archaeological excavations mainly in the coal mining areas nevertheless showed that even regular settlements were the result of later transformations. Like in Southern Germany, the possibility of subsequent changes was underestimated ${ }^{15}$.

In the 1970s an increasing demand for development areas caused a growing number of rescue excavations in medieval rural settlements of southern Germany. The invention of the hydraulic backhoe made it possible to investigate large areas. For example, in the surroundings of Munich many early medieval settlements were discovered in the periphery of the later villages. Inspired by research in Iron and Viking age settlements in Scandinavia archaeologists recognized the changing nature of early medieval settlement patterns ${ }^{16}$.

Still today, the best documented example from southwest Germany comes from the Renningen basin situated in a fertile region west of Stuttgart between the Neckar valley and the Black forest, researched in the late 1980s/ early 1990s (fig. 3) ${ }^{17}$. Starting with two settlement areas during the migration period, a dispersed settlement system was established in the course of the early and high Middle Ages. However, with a settlement in the «Neuwiesenäcker» situated nearly halfway between the later villages of Renningen and Malmsheim one of them developed to a kind of a 'core area' with a bigger settlement. Excavations unearthed rural post houses as well as pit houses, fences and water wells. While there were also older finds, the excavated features date to the $11^{\text {th }} / 12^{\text {th }}$ century, thereby indicating settlement relocations. In this area we can find the toponym of "Altheim» (meaning 'old settlement') close to the toponym «Neuwiesenäcker» (meaning 'fields at the new meadows') for the late Middle Ages. In fact, the settlement area was altered to agrarian land after the $12^{\text {th }} / 13^{\text {th }}$ century. Spreading around this core settlement were dozens of small sites. Most of them are only known by ploughzone pottery finds from systematic fieldwalking and miss single point measurements as well as a registration of modern finds, which could be indicative for secondary deposition. Because of the distinct find inventories ending in the $12^{\text {th }} / 13^{\text {th }}$ century and excluding late medieval sherds they are indicative for settlement locations. These small settlement sites start in the Merovingian period in areas close to the flood plain and then, over the course of time, spread to more peripheral areas including locations with poorer soils. In the $12^{\text {th }} / 13^{\text {th }}$ century this settlement expansion reached its peak and collapsed afterwards. The settlement pattern was reduced to the villages of Renningen and Malmsheim.

15 Comp. Biermann (2010); Spazier (2005).

16 Steuer (1988); Kossack (1988).

17 Schreg (2006). 

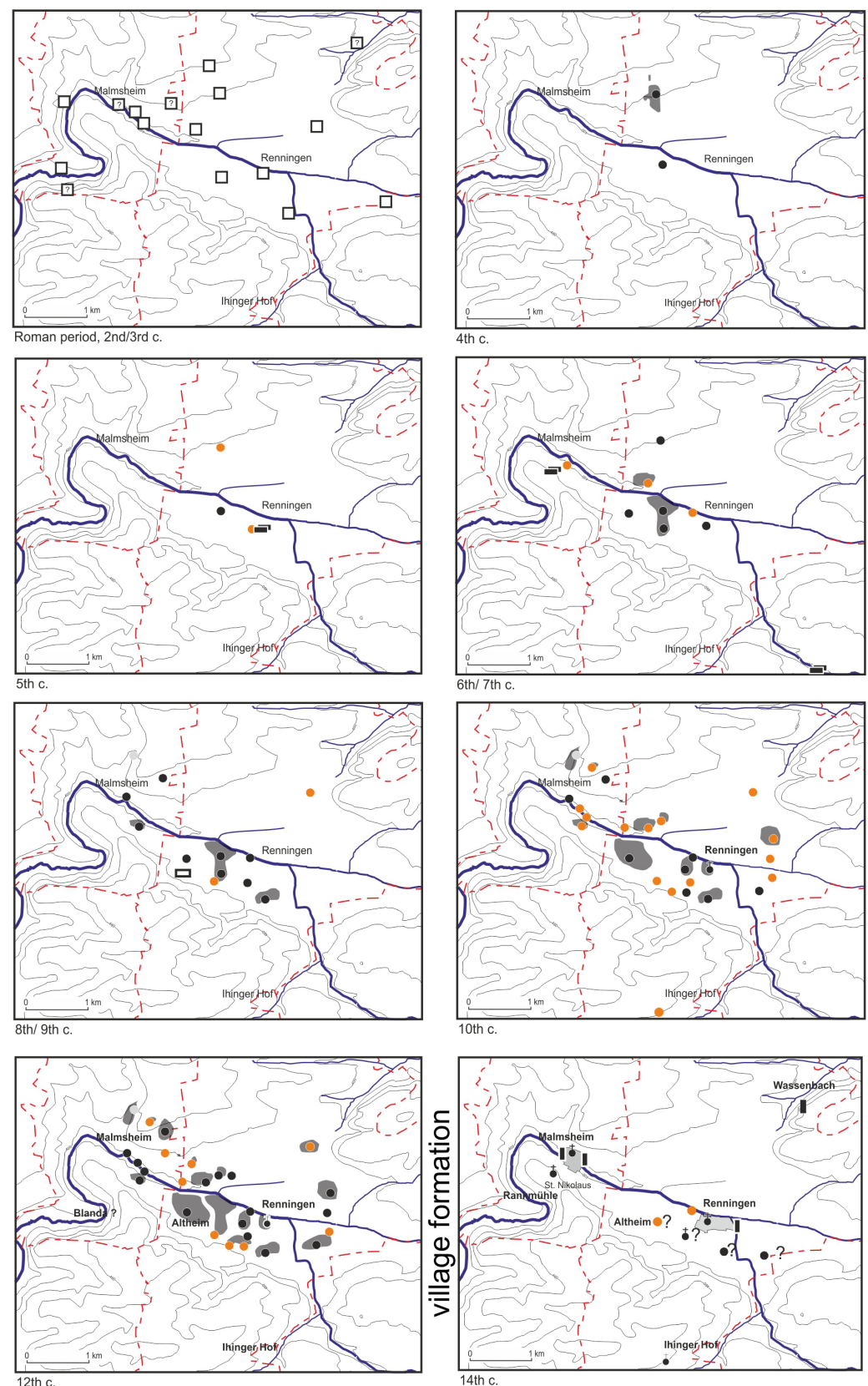

Figure 3. Settlement change at the Renningen basin. 
Another example comes from the surroundings of the medieval episcopal city of Speyer ${ }^{18}$. South of the city along a former bank of the river Rhine, a medieval settlement site has been excavated. We do not know much about other settlements dispersed in its vicinity, as the potential area for these has long destroyed by modern developments, but the analysis of pottery finds shows a continuous relocation of settlement activities from east to west. In the last phase, farmsteads were clustered around a small church (fig. 4).

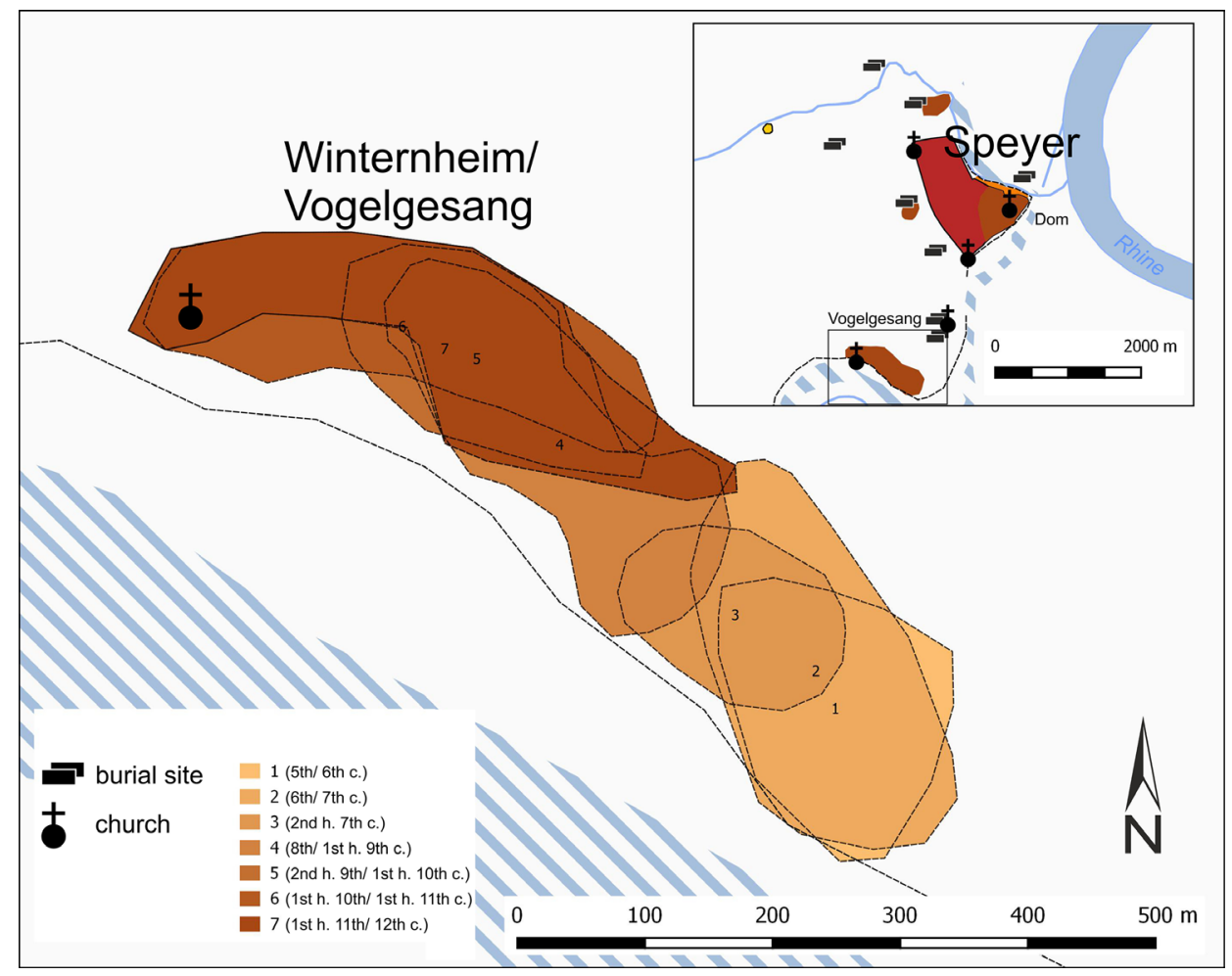

Figure 4. Settlement relocation at the abandoned settlement Winternheim/Vogelgesang south of Speyer.

These examples refer to a highly flexible system of shifting settlements up to the High Middle Ages. The typical nucleated village surrounding a church and connected with an open field system was the result of a settlement concentration during the $12^{\text {th }} / 13^{\text {th }}$ century, in some regions dating a bit earlier ${ }^{19}$. In more marginal landscapes of low mountain ranges -often recognised as late settled areas of medieval colonisationthere were similar processes of settlement reorganisation. Settlements like forest villages with long strip plots behind the farmsteads were previously understood as settlements

18 Bernhard (1982).

19 Schreg (2019a). 
founded and planned within an organized colonisation, but archaeological research gives evidence for more complex processes involving the relocation and concentration of settlements ${ }^{20}$. Important examples for this process come from the Paris basin ${ }^{21}$, from Northern Germany and Jutland ${ }^{22}$, and also from England ${ }^{23}$.

This increasing database meets a time when medieval archaeology shows an emancipation from the discipline of history. This does not mean that historical sources are neglected. On the contrary, a critical reflection of approaches coming from anthropology, cultural sciences as well as from sociology or ecology provides the basis for a more critical analysis of the past, bringing together very different sources. Especially social and ecological archaeology makes use of models of human-ecosystems, which help to bring together perspectives of historical individuality and structural models ${ }^{24}$.

\section{IDEOLOGIES OF THE PAST}

We have already seen the significance of a long tradition of the rural village for nationalsocialist ideology. Despite fundamental differences in the idea of historical evolution, the Marxist view also took the primordial village ("Urdorf») for granted. Marxist historical materialism understood history as a social process driven by the conflicts deriving from the modes of production. History in this view is determined rather by material conditions than ideas. Human societies went through several stages; primitive communism, slave society, feudalism, and capitalism. The transformation from one stage to the next occurred by revolution, because the ruling groups were interested in preserving the existing modes of production. Through social and political upheaval, lower classes introduced a new system of production. Agency was seen as lying rather with the masses than with individuals. Peasants' agency has for example been seen in the $16^{\text {th }}$ century's peasants' war, but eventually the bourgeoisie carried out the French Revolution, whereas peasants played only a minor role in it. Marxist history followed an evolutionary, to some degree cyclic idea of history. Structures therefore had greater importance than events or individuals ${ }^{25}$.

Nevertheless, the Marxist narrative of the medieval village, as present in the work of Friedrich Engels or Rosa Luxemburg, was also a story of continuity. They argued that relics of the primitive primordial society were still preserved within the medieval villages. The commons, which were an important part of the village economy in the late middle ages, were the remains of earlier common property.

20 Schreg (2014b).

21 Gentili, Lefèvre (2009).

22 Holst (2010).

23 Hamerow (2002); Loveluck (2013), pp. 86-91.

24 Comp. D. Gronenborn-R. Schreg, Kleine Geschichte der Erforschung von gesellschaftlichen Zyklen. Die COVID-19 Pandemie - Teil 2. Archaeologik, 9.4.2020. https://archaeologik.blogspot. com/2020/04/die-covid-19-pandemie-teil-2-kleine.html.

25 Fuchs (2020). 
What many early interpretations have in common is the understanding, that rural life did not change over time. Universal historian Oswald Spengler (1880-1936) for example regarded peasants as "timeless» and "without history»" ${ }^{26}$. Caught by the permanent change between sowing and harvesting, nothing should have changed over centuries or even millennia in this traditional view. This idea also affected historical and archaeological research related to medieval villages. The paradigm of a long-lasting tradition of villages precluded any idea of fundamental changes in settlement history. Research on village formation was just not necessary, as the villages were thought to go back at least to the migration period if not to the first farmers in the Neolithic.

After WW II ideas about medieval settlements started to change. Historians researched medieval villages in southern Germany and adjoining districts of Switzerland and Austria in numerous studies. In the 1950s Karl Siegfried Bader (1905-1998), a historian of law started to analyse the regional written record. He published three volumes on the changes of legal institutions ${ }^{27}$. As a result, he dated the formation of the rural community to the $11^{\text {th }} / 12^{\text {th }}$ century, based on written documents mainly from southwestern Germany. At that time, there was a prominent debate among historians about the existence of free peasants and the organisation and development of feudal power ${ }^{28}$. To date, it became clear, that medieval society was less formally organized than the history of law, based on $19^{\text {th }} \mathrm{c}$. ideologies though, suggested. Power was a matter of constant negotiations ${ }^{29}$, involving social communication by personal contacts, rituals, written documents but also material culture. Communality has been identified as a characteristic of the medieval society ${ }^{30}$. Peasants gained more attention in research, but still institutions played an even greater role in the analysis of the rural world.

However, in the second half of the $20^{\text {th }}$ century many other perspectives on the medieval and early modern village emerged. Studies in the sphere of the French Annales did not reach German historiography for a long time. Some of the Marxist traditions of the Annales were not compatible with German traditions in historicism ${ }^{31}$. However, when in the late 1960s social history and later micro history evolved, also in Germany material preconditions gained more attention. Several studies provided detailed analyses of single village communities ${ }^{32}$. Since more recent years, environmental history has been interested in landscape changes and agriculture and causes new narratives of men-environment-interaction.

Important impulses come from social sciences, understanding culture as a matter of communication and social processes. In general, a stronger focus on communication and social interaction challenges previous normative views used by many historians and archaeologists. Regarding medieval settlement history they often tried to establish distinct




characteristics e.g. for 'nobility, 'villae', 'curtes', 'marcae' or 'Gaue'. ${ }^{33}$ They presumed, that there was a common definition and a planful central implementation. However, - this classification of material culture by contemporary terms proved to be a difficult methodological problem ${ }^{34}$, because most studies showed a broad variety of archaeological features.

\section{A DISCREPANCY BETWEEN THE ARCHAEOLOGICAL AND THE WRITTEN RECORD}

To some extent, there is a contrast between the historical evidence and the archaeological one ${ }^{35}$. Whereas the written sources stress continuity and the role of the elites, the archaeological data refer to fundamental changes in the settlement pattern, which are not clearly visible in the documents. Archaeological data challenged the traditional views of the medieval village for quite a long time, as it did not show unbroken continuity from the early Middle Ages or even the Migration period until modern times. Instead, it showed a transformation from a rather dispersed, fluctuating settlement system to permanent, nucleated villages. It also showed a radical change in rural architecture. In the early Middle Ages, post houses and also pit houses were characteristic, whereas in the late Middle Ages more complex architectural structures in timber framework or even stone architecture were common.

However, historical sources have little direct evidence for the physical settlement changes proven by archaeology. From written sources we can trace structural changes, but it is very hard to pin-point them down in the settlement landscape. Despite these revolutionary changes of settlement pattern, there are no documents certifying the redistribution of land, which necessarily though must have taken place back then. There are no orders or regulations by the authorities regarding settlement changes. And finally, there are no sources which document any court trials about conflicts, which for sure resulted from these changes. This is remarkable, as we know at the latest from the Carolingian period onwards quite many written sources about land transactions, orders, and court judgments in other cases.

Written sources reflect the genesis of the village in general, but they do not represent the actual changes and conflicts that must have taken place according to the archaeological evidence. Hence, there is a discrepancy between the written and the archaeological record.

\section{Formation PROCESSES OF THE ARCHAEOLOGICAL AND HISTORICAL RECORD}

Searching for an explanation of this discrepancy, we need to take a closer look at formation processes. Michael B. Schiffer has developed this concept in the context of the

33 Schumacher (1925), pp. 209-212, 271-308; Hinz (1967).

34 Comp. Andrén (1998), pp. 153-177.

35 Comp. Zadora-Rio (1996). 
New Archaeology of the $1960 s^{36}$, but it may be also useful for analysing the historical tradition. The concept distinguishes several stages of formation processes ${ }^{37}$.

The primary formation results from the activities of the people of the past, but not all of them produced traces that we can use as historical sources. Whereas some of them are created intentionally to invent a tradition, most are just the casual remains of everyday activities. In principle they represent all levels of society. Though, poor people without their own houses, owning just few belongings may be underrepresented. Nevertheless, this is an important contrast to the written record. Only few people were able to read and write and therefore a written documentation was only reasonable in few special contexts. This was the case for example, when complex holdings had to be organised in the framework of the manorial system. Written documents were of little use in the context of rather illiterate communities. The same is true for orders or charters, when written content was less important than the affirmative function of the document itself. The written record therefore represents only a specific segment of the society.

The secondary formation reinforces the bias between peasants and elite perspectives. Regarding written sources, texts have the best chances to survive if they are hosted by institutions which have high continuity. Most written sources of the early Middle Ages therefore have a clerical background. In the late Middle Ages, towns and the beginning territorial states preserved a remarkable written tradition, but again, peasants do not have a voice.

In archaeology, secondary formation can also broaden the social gap. Material culture of poor people has fewer chances of preservation. Ceramics for example may be low-fired, less hard and therefore more prone to the risk of weathering. Wooden huts or shielings leave only few traces, whereas elite houses may be well preserved because of their stone architecture and later renovations and maintenance. Secondary formation processes can be specific for different time periods. Early and high medieval villages in Central Europe are characterized by wooden buildings and pit houses, which leave the traces of dugouts, even if the original surface is destroyed. Late medieval houses are in general rather constructed on beams or stone foundations at ground level, pit houses had become untypical. Therefore, it is quite hard to detect traces of late medieval farmsteads within existing villages, where later activities often disturbed the old surfaces.

As a result of primary and secondary formation processes, there is a potential for historical or archaeological sources, which however need valorisation and interpretation. This stage is characterised by tertiary and quaternary formation. Tertiary formation includes all procedures of prospecting, excavating, and documenting archaeological sites and finds. It is easily understandable that excavation techniques and collection strategies for example affect data quality. Therefore, the interpretation of archaeological and historical data may be understood as a different procedure, even if there is a hermeneutic relation between documentation and interpretation. Interpretation is affected by theoretical perspectives, whether they are applied explicitly or implicitly. Theories in archaeology have gained more attention since the New Archaeology in the 1960s and 70s tried to

36 Schiffer (1987).

37 Schreg (2016b). 
establish a more transparent interpretation by applying distinct theoretical approaches. Medieval archaeology -at least in Germany- refused theoretical debates as coming from cultural anthropology, but also missed a critical reflection of other conceptions of history.

The question of peasants' agency represents a wonderful example showing many different presuppositions and paradigms. Archaeologists and historians were often neither aware of the consequences of primary and secondary formation, nor of the importance of the reflection on theoretical backgrounds as influencing general ideas of the past.

\section{Peasants' agency in settlement change of Southern Germany}

As we have seen in the previous sections, our views on settlement history evolved because of an increasing archaeological data base, but also because of a changing theoretical background. Instead of the traditional top-down perspective emphasizing the role of institutions and power, more recent theories emphasize social behaviour on the one hand and environmental factors on the other ${ }^{38}$. All these concepts have different approaches regarding the meaning of agency.

We will look now at four episodes of medieval settlement history of Southern Germany, which show, that we must consider a more active role of peasants.

\section{THE EARLY MEDIEVAL SHIFTING SETTLEMENTS}

The phenomenon of shifting medieval settlements was first recognized in Northern Europe but is also present at many sites in Southern Germany ${ }^{39}$. The relocation of settlements was most often a process going on over generations, usually only in small steps. The farms of the Vogelgesang settlement south of Speyer, for example, moved slowly westwards along the edge of the terrace to the Rhine over several hundred years (fig. 4). In Mengen im Breisgau two spatially separate settlement sites were relocated in opposite directions enlarging the distance in between ${ }^{40}$. We know that a shifting settlement system was present at many places in early settled landscapes, but we can currently not estimate how widespread it was. At some sites, excavations show the presence of settlement activities at one spot over centuries, but because excavations were restricted in size, it is not for sure, what happened in the surrounding areas. In fact, we also face several problems when it comes to an evaluation of settlement systems via archaeological data. A major problem is the lack of large-scale analysis of settlement landscapes. We urgently need large scale prospection by geophysics and appropriate surface collections registering not only prehistoric but also medieval and later finds by single point measurements. Currently this is primarily the work of amateur archaeologists, who are often more interested

38 Schreg (2016d); Dommasnes, Gutsmiedl-Schümann, Hommedal (2016).

39 Steuer (1988); Schreg (2006), pp. 303-317; Schreg (2012c).

$40 \quad$ Schreg (2006), pp. 228-232. 
in collecting finds than documenting data. Another problem is the weak chronological resolution of some of the most important regional ceramic groups in southern Germany.

The background of and the reasons for early medieval shifting settlements are quite unclear, as there is no direct evidence by written sources. Archaeological data shows a slow relocation of farmsteads. Settlements normally stayed at one location for more than one generation. Therefore, it is unlikely to link the phenomenon of shifting settlements with social practices related to generation change and inheritance. Rather, the motivation to rebuild the farmsteads again and again at a slightly different location seems to have something to do with soil management. Ethnographic examples of shifting cultivation come from sparsely populated landscapes mostly from tropical environments. New fields were cleared every year and when the distance became too long, the houses were moved to a spot closer to the fields. During time the settlement shifted over a vast area. In Southern Germany, we can trace a shifting cultivation during the later Neolithic for pre-alpine lake dwellings. Dendrochronology refers to rather short cycles of settlement movement. At some sites at the banks of lake Constance we may assume relocation of just a few kilometres ${ }^{41}$. However, in the early Middle Ages this kind of a typical shifting cultivation with new clearances every year is unlikely. Assumed relocations took place too slowly and only over too short distances. More likely, early medieval shifting settlements were based on a long-term change of fields, gardens and habitation areas that may have prevented soil exhaustion. Within the area of the farmsteads, there was an accumulation of nutrients in the soil by waste and dung. Gardens at the houses were probably fertilized by compost, whereas the soil on the fields was exhausted over the years. The only manuring was most likely due to regular grazing during fallow periods. The typical spread of ceramic sherds that is an indication for manuring the field by droppings, only dates to the late Middle Ages and early modern period.

Despite the open questions regarding the shifting settlement system, it shows that soil property must have been quite flexible. Even within the settlements, which stayed at one place over centuries, like Berslingen for example we can see a reorganisation ${ }^{42}$, which probably involved different landowners. If shifting settlements were part of a land use strategy, land property was possibly rather at a communal basis and object to land distributions among the local peasants.

This insight is critical, as it refers to the old debate about the development of land property. Whereas a Marxist view postulated common property and early researchers referred to the 'Germania' of Tacitus mentioning land property among 'Germanic' tribes ${ }^{43}$, later research took private land property as granted. When in 1989 the French historian Guy Bois dealt with the rural community of Lournand close to the abbey of Cluny, he observed the development of a property market ${ }^{44}$. Because of his Marxist conception, his work was ignored in Germany, but in the meantime detailed regional studies confirmed

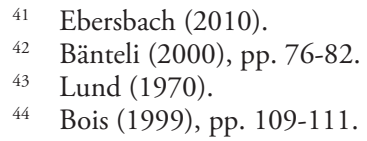


structural changes within land property rights ${ }^{45}$. Early medieval rentals mainly describe the size of the land and the amount of taxes the peasants had to pay to their lords, but they normally do not refer to specific field plots. In contrast, late medieval and early modern rentals register single fields, giving their location by listing the area within the three-field-system, toponyms and sometimes even the names of the cultivators of neighbouring fields ${ }^{46}$.

\section{THE INTRODUCTION OF A REGULATED OPEN FIELD SYSTEM AND VILLAGE FORMATION}

Whereas these early medieval relocations were an ongoing process over centuries, the high medieval village formation ceased this practice. From the $11^{\text {th }}$ to the $13^{\text {th }}$ century onwards settlements stayed at a permanent location. There was a drastic restructuring of the settlement pattern including a concentration of single farmsteads and hamlets. This village formation and its underlying concentration process is unthinkable without affecting land property rights.

Village formation in the old settled agrarian landscapes of the lowlands also had a major impact on land property. The nucleation of numerous small farms and hamlets in a central village was for sure not possible without a redistribution of land. Former settlement areas were turned to agricultural land. In some well-preserved sites in the Netherlands traces of later ploughing were observed during excavations ${ }^{47}$, in Jutland the comparison of fences in the settlements of Vorbasse and Norre Snede refers to shifting settlement locations within a more constant system of field borders ${ }^{48}$. At Renningen the toponym «Neuwiesenäcker» (meaning "fields at the new meadows») refers to a transformation of a former settlement area to agrarian fields.

According to the idea of the timeless peasant researchers of the $1^{\text {st }}$ half of the $20^{\text {th }} \mathrm{c}$. understood the open field system as «rooted to the soil», going back to earliest times ${ }^{49}$. For sure though, the open field systems as they are typical for the late Middle Ages and early modern period do not predate the reorganisation of the settlements in the $12^{\text {th }} / 13^{\text {th }}$ century. Within this new system the agrarian land of a village was divided into three large field complexes, which were cultivated within the same rhythm. These field blocks were called «Zelgen» or «Esche», both terms also used earlier with more general meanings. As the medieval language used traditional terms, individual three-field crop rotation and the regulated three-field system have become mixed up. A Carolingian origin of the regulated system cannot be proven because the terminology of the sources is too unspecific. A detailed analysis of the written sources has shown that the communal regulation of the cultivation of the agrarian fields is only visible in documents of the $11^{\text {th }} / 12^{\text {th }}$ centuries $^{50}$.

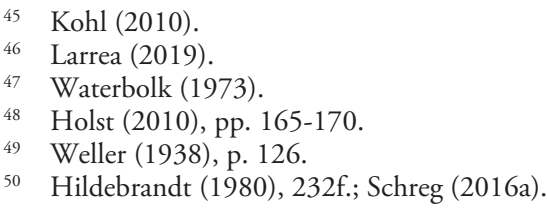


In the late Middle Ages however, it is obvious by the context of rentals, that terms as «Zelg» or «Esch» refer to the three field complexes of the regulated open field systems.

This reorganisation of agriculture in a communal framework was most likely connected with the village formation. For the system to work, each farmer had to cultivate equal parts of land in each of the three field complexes. Furthermore, it is practical to have the farmsteads concentrated in a nucleated village in the centre of the agrarian land. Farmsteads and all agrarian fields had to redistributed. There was a high need for coordination and regulation involving the peasants of different seigneuries and owners.

Previous research could not think of the regulated three-field system without an organisation by authorities. In fact, there were regulations called districtus et bannus (compulsion and interdiction, German «Zwing und Bann»).

For sure, landlords benefited from the introduction of the regulated three-field system by higher yields and taxes. However, it is not for sure, that they were in fact the decisive drivers behind its introduction. In the late Middle Ages there were typically several landowners, and more than one lord or authority in one village. The open field system needed agreements for the new regulations. Presumably if lords were involved, this process should be visible in the written record, but it is not. There are no direct sources describing the introduction of the open field system and the changes of the rural landscape.

Historians called the introduction of the regulated three-field crop rotation within the open field system one of the most important revolutions of the Middle Ages ${ }^{51}$. However, there is only sparse information from written sources. Only in late medieval documents it becomes clear, that the regulated open field system was in place. It is important to notice, that the innovative element was not the crop rotation between winter grain, summer grain and fallow. This is something every farmer can do individually. Roman writers on agriculture already describe crop rotation ${ }^{52}$. The important point is the communal organisation involving all farmers of a village. Because the crop rotation was already known before and was feasible for every individual field, there were probably other reasons for the introduction of the regulated open field system.

The coordination between all the village's farmers made it possible to abandon the individual field enclosures - usually hedges or field walls made of rubble, both types several meters wide. It was also possible to abandon access roads. As all farmers within one field complex had to cultivate their fields in the same way, there was no crop damage by trespassing neighbouring land. Husbandry of several owners grazed during the fallow period together in one Zelg and did not have to be penned on a single plot. The removal of the physical field enclosures resulted in the gain of additional arable land. It also allowed a more effective ploughing of the field as the harnessed team could work in a straight line up to the end of the field and turned around on the neighbouring property. These benefits come from daily life practice and probably not from landlords, even though they certainly often had strong ties to rural agriculture ${ }^{53}$.

51 White, junior (1968), p. 63 (original engl. ed.: White (1962)).

52 E.g. Vergil, Georgica, I,17; Columella, De re rustica, II,9; Schröder, Lembke (1978), pp. 3-11.

53 Schreg (2018b). 
The introduction of the regulated three-field system must have had several consequences for the entire landscape ecology (table 1). The removing of hedges and the establishment of big field complexes cultivated in the same way increased the risk of soil erosion and changed the hydrology and microclimate. Fur sure there were also effects on biodiversity, as the removing of hedges destroyed biotopes of birds, rodents, and insects. During fallow period, the animals of the village were herded together, increasing the risk of epidemics of animal diseases. Furthermore, the removal of hedges probably affected the supply of raw material for the construction of houses and fences or wooden tools and other wooden objects, and it may have reduced the possibilities for additional gathering of nuts and fruits.

\begin{tabular}{|c|c|c|}
\hline Landscape with enclosures & $\begin{array}{l}\text { Furlong complexes of open } \\
\text { field system }\end{array}$ & $\begin{array}{l}\text { Consequences of the invention } \\
\text { of field complexes }\end{array}$ \\
\hline $\begin{array}{l}\text { field pattern of blocks with } \\
\text { several settlement areas }\end{array}$ & $\begin{array}{l}\text { furlong complex with } \\
\text { distributed land property }\end{array}$ & $\begin{array}{l}\text { settlement concentration within a } \\
\text { nucleated village }\end{array}$ \\
\hline \multirow[t]{2}{*}{$\begin{array}{l}\text { freedom of decision in } \\
\text { cropping }\end{array}$} & $\begin{array}{l}\text { regulation of cropping by the } \\
\text { community }\end{array}$ & $\begin{array}{l}\text { consolidation of communal } \\
\text { institutions }\end{array}$ \\
\hline & & village formation \\
\hline $\begin{array}{l}\text { husbandry in separate plots } \\
\text { and rather small herds }\end{array}$ & large common herds & $\begin{array}{l}\text { increased risk of epidemic animal } \\
\text { diseases }\end{array}$ \\
\hline $\begin{array}{l}\text { small scale mosaic with } \\
\text { different cropping }\end{array}$ & $\begin{array}{l}\text { field complexes as open fields } \\
\text { with homogeneous crop }\end{array}$ & $\begin{array}{l}\text { large areas with homogeneous } \\
\text { crop }\end{array}$ \\
\hline $\begin{array}{l}\text { hedges around the single } \\
\text { field plots }\end{array}$ & $\begin{array}{l}\text { hedges around the large field } \\
\text { complexes }\end{array}$ & $\begin{array}{l}\text { many hedges cleared } \\
\text { reduced biodiversity }\end{array}$ \\
\hline reduced water-runoff & increased water runoff & increased risk of soil erosion \\
\hline reduced heath emission & increased heath emission & \multirow{2}{*}{$\begin{array}{l}\text { sinking ground water level } \\
\text { increased risk of local extreme } \\
\text { weather }\end{array}$} \\
\hline reduced evaporation & increased evaporation & \\
\hline & & $\begin{array}{l}\text { transformation of the cultural } \\
\text { landscape and of landscape } \\
\text { ecology increased ecological risks } \\
\text { (esp. during extreme weather) }\end{array}$ \\
\hline
\end{tabular}

TABLE 1. Ecological consequences of the open field system.

It is a task for archaeologists to trace these changes. At this time, we know about village formation, but we can only make assumptions about the agrarian land. By now, there is little research on medieval agriculture which could allow tracing these hypothetical changes in all details. We have some evidence of medieval soil erosion, but the hydrological and climatic effects are only suggested by modelling of other periods ${ }^{54}$. Archaeologists often lack the ecological understanding which is necessary to identify, document and analyse the preserved evidence. We still lack for example modern research on field systems going beyond the typological questions, which were an important topic

54 Müller (2004), p. 86. 
for historical geography in the past. We need to register fossil field systems to verify the removal of hedges and the reorganisation of field plots. We need to establish a date in time for this process and we need to investigate the effects of the open field system on the landscape.

The understanding of field systems requires an ecological perspective, which only developed in recent decades. Environmental history and ecological archaeology have gained in importance since the 1970s, when environmental problems became more and more evident. Recent studies from southern Scandinavia, England or from the Benelux countries show the potentials of approaches of 'landscape biography'. In many cases these studies were based on landscapes where medieval field structures are better preserved than in most German regions. In England the shift from agrarian to pasture land preserved field structures as the remains of ridge and furrow. In the coversand region of the Netherlands for example plaggen soils covered and protected the archaeological traces of field ditches enabling the reconstruction of the transformation of field systems ${ }^{55}$. The environmental perspective made researchers aware of complex interconnections and the role of human ecosystems, which also includes the peasants and their daily interaction with the environment and the cultural landscape ${ }^{56}$.

\section{8}

Pioneers ANd PeOple Without a Voice: medieval Colonisation Processes

Parallel to the village formation the medieval colonisation of marginal landscapes took place. This expansion of settlements to coastal or riverine landscapes, low mountain ranges and high mountains was necessary because of an increasing population growth, which is of course hard to quantify.

Archaeological data from Southern Germany challenges previous ideas of organised clearances opening the wilderness for civilisation. Recent geoarchaeological research has been able to demonstrate soil erosion and sedimentation processes in various low mountain ranges, which often predate the time when written sources and geographical data from toponyms and settlement forms suggest a colonisation. There is an increasing number of indications that the so-called territorial expansion, connected with place names, the construction of castles and monasteries, and sometimes even the foundation of towns, is rather a reorganization of earlier land use than a colonisation of pristine wilderness ${ }^{57}$.

The concepts of "state colonisation" ${ }^{58}$, and «Rodungsburgen» (castles as initial point of forest clearings $)^{59}$ or the pioneering role of monasteries ${ }^{60}$ show the usual top-down perspective, not taking any agency of peasants into account. For sure, noble families and

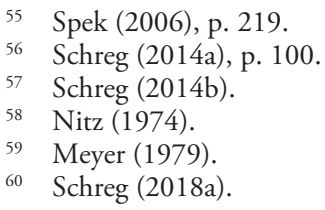


monasteries played an important role in the evolution of cultural landscapes in marginal land, but in many cases, there had existed land use by local people before that.

In the northern Black Forest the village of Würzbach shows that the process of colonisation was more complex. The existing village represents an ideal example of a forest village with long strip plots behind the farmsteads (Waldhufendorf). Researchers took it for granted, that their regular form is caused by a planned foundation by noble or clerical authorities in the $11^{\text {th }}$ century. Written sources mentioning Würzbach among the Carolingian possessions of Hirsau monastery were doubted in their authenticity and the colonization of the region was closely related to the renewal of the Carolingian-era monastery of Hirsau at the end of the $11^{\text {th }}$ century. Later research questioned this idea, and in more recent times archaeology found many examples showing that regular village plans as they are present in late medieval texts and early modern maps are often the product of a long-lasting evolution and a transformation of earlier settlement patterns. In the case of Würzbach archaeological data shows in fact a long-term transformation. There are several settlement sites predating the later Waldhufendorf -a situation like that at the villages of the old settled fertile landscapes. Soil sediments in their surroundings belong to clearance processes before the $11^{\text {th }} \mathrm{c}$. colonisation, maybe even before the founding of Hirsau monastery. The Waldhufendorf, as it is visible in historical texts and maps, is the product of a complex process. It was not based on one distinct plan, because late medieval rentals of Würzbach use two different measurement systems for the description of the farmsteads. This implies that there was more than one 'founder' involved. South of the present village around 20 farmsteads were abandoned at around 1400 AD. Their remains, well preserved in today's forest, continued the structure of the Waldhufendorf. We do not know whether this was a reduction or relocation of the earlier settlement ${ }^{61}$.

Not only regularly 'planned' settlement structures may be misleading. In addition, toponyms, which were often used for a reconstruction of colonisation processes are no reliable source. Based on their typical endings they were sorted into several phases and dated by a correlation with early medieval cemeteries and their presence in written documents. However, there is a confusion of naming and founding of the settlements. Probably, the development of settlement names was itself a process, depending on the local social organisation, economic relevance and the needs of communication. Many early medieval settlement names in southern Germany were ending on «-ingen» referring to clans. Later names explicitly point to settlements (ending e.g. with «-heim», «-hausen» or «-stetten») or landscape elements as rocks, valleys, creeks or forests («-stein», «-tal», «-bach» or «-wälden»). The last ones are even younger and typical for marginal lands. Sometimes there are names referring specifically to the uprooting of trees (e.g. «-roden»), which is why these settlements are considered the result of a systematic colonisation. However, in Southern Germany there are finds indicating that settlement activities can in fact predate the presumed dating of the related place names ${ }^{62}$. Most research combining archaeological data and toponyms was based on Merovingian burial sites but did not refer to settlement remains.

61 Schreg (2013b); Thode (2015).

62 Schreg (2008), pp. 303-305. 
In the case of medieval 'colonisation' there are sometimes written sources documenting long lasting conflicts between colonizers and local peasants. This is the case in the Palatinate forest west of the upper Rhine close to the monastery of Eußerthal. Obviously, the monastery occupied land that local peasants reclaimed as their commons. Archaeological finds point to an early medieval forest economy including tar production and charcoal burning. Even a remarkable clearance of trees must have taken place, as erosion gullies dated to the early Middle Ages indicate ${ }^{63}$.

The monasteries of Eußerthal and Hirsau are at first glance situated in remote valleys far from civilisation, but landscape archaeology most often dispels the myth of loneliness and pioneering clearance. Rather, monasteries and castles followed the first settlers who were engaged in forest economies. Medieval colonisation in mountainous and forested landscape did not deal with pristine wilderness. The medieval glorification of monastic life as a life in solitude themed ora et labora provides a perspective neglecting the agency of peasants. On the other hand, the image of pioneering initiatives by monasteries and noble families is also influenced by anachronistic, modern perceptions of history and nature $^{64}$.

I $4^{\mathrm{TH}}$ CENTURY CRISIS

Earthquakes, extreme weather events, a plague of locusts, bovine pestilence, and the bubonic plague in the $14^{\text {th }}$ century caused famine, calamity, and death ${ }^{65}$. Contemporary accounts, such as those of Konrad von Megenberg (1309-1378) or Heinrich von Herford (c. 1300-1380), are suggesting a deep, comprehensive crisis, which was not only due to these catastrophes, but also to several technological innovations of the early $14^{\text {th }}$ century, like firearms or church clocks. However, these contemporary narratives do not give detailed information about deserted settlements, which in fact are a very common phenomenon of most landscapes in southern Germany at the end of the $14^{\text {th }}$ and the beginning of the $15^{\text {th }}$ century ${ }^{66}$. The site of Würzbach in the Black Forest, mentioned before, is just one example.

Researchers have developed many hypotheses for the causes of late medieval settlement abandonment. They cover a huge spectrum, starting with a failure of colonisation by mistaken locations, migration into newly founded towns, destruction in wars and feuds, or extinction during the Black Death. Most of them tried to find specific events behind the abandonment of settlements. Remarkably, most interest in the topic does not come from academic historians, but from geographers, economists or local historians. The late medieval crisis did not fit into the common narratives of progress and national splendour. When Otto Schlüter presented a reconstruction of the development of

63 Schreg (2018a), pp. 45-47.

64 Schreg (2014b), pp. 88-91; Schreg (2018a), 47f.

65 Bauch, Schenk (2019).

66 Comp. Schreg (2019b). 
cultural landscapes in the 1950 s, the crisis was a short intermezzo ${ }^{67}$. This view neglects, that still today the traces of many late medieval settlements including their agrarian land are covered by forests. Still today we lack a comprehensive understanding of the crisis, as this requires a systemic perspective which is different from traditional ideas of history. Wilhelm Abel, a historian of economics argued that the Black Death caused an economic crisis, because the demand for agricultural products declined ${ }^{68}$. As wages of labourers were raised at the same time, many farmsteads primarily in marginal landscapes lost their rentability and were thus abandoned. This theory, developed in the 1930s, provided for the first time a systemic explanation. In recent years, there have been several research papers from the field of environmental history that argue for a primarily ecological crisis in the $14^{\text {th }}$ century, due to the beginning of the Little Ice Age ${ }^{69}$. Soil sciences identified effects of soil erosion and referred to the St. Mary Magdalene flood in July 1342 just a few years before the Black Death ${ }^{70}$.

As we have seen in the previous sections, there were major changes within the settlement system affecting the cultural landscape and increasing their vulnerability (tab. 1). The open field system destroyed hedges and biotopes, changed the evaporation and heath emission, created new risks of soil erosion, and prepared the ground for infectious animal diseases. A verification of hypothetical interconnections between the Black Death and the preceding changes in agricultural practice depends on solid data of the chronology of settlement desertion, detailed reconstructions of landscape changes and the genetic detection of yersinia pestis and other pathogens. In the end there might be a scenario, that assigns major responsibility for the $14^{\text {th }} \mathrm{c}$. crisis to the peasants -or to agricultural practices.

It is an open research question to understand the different processes, their complex interconnections, and the agency of the various stakeholders ${ }^{71}$. Again, interpretation depends on a general understanding of how history happens or is created.

\section{Peasants OR LORDS?}

All four episodes of medieval settlement history in southern Germany raise the question who was responsible for these changes. Several studies addressed aristocratic power in medieval landscapes in western and southern Europe showing the role of communication in rural communities, peasant solidarity and collective agency during the Middle Ages $^{72}$. This new research challenges traditional historiography, which tended to point to the lords (or monasteries). Within this last section we will briefly reflect upon the archaeological evidence mainly from Southern Germany on the role of peasants and lords within the rural communities.

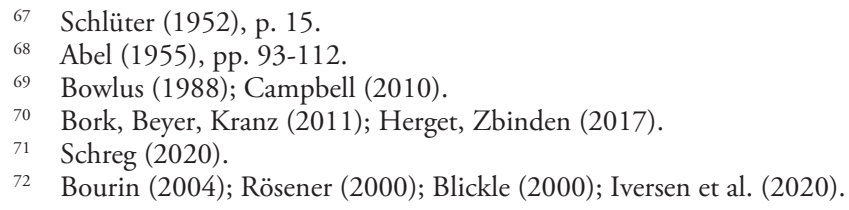




\section{Castles and manors}

The ruins of castles and monasteries are striking, as they are normally more representative and better preserved than seasonal shielings or the huts of lumbermen. Written as well as archaeological sources clearly depict the lords as major stakeholders within the processes of medieval landscape transformation. They had an interest in an effective agriculture as this increased their income. Nucleated villages allowed a better control of the population; the open field system with permanent fields made the tax administration easier.

Moated sites within the context or rural villages show the complex relation between lords and peasants. By their number they are more important than castles built on top of a hill, which dominate our imagination about medieval castles. It is important to notice, that by now we do not have enough data to understand the relation between the development of moated sites and village formation. In most cases we do not know the origins of rural castles, as written sources are scarce and still today there are only few excavations $^{73}$. Only few examples, like the pioneering excavations at Husterknupp in the Rhineland allow us to trace the development from the $9^{\text {th }}$ century onwards $s^{74}$, but in most cases the excavated remains only date to the late Middle Ages. In southern Germany there is an irresponsible gap in research on moated sites in rural contexts. In spite of uncountable evidence in written sources and toponyms there exists to date only a handful of excavations. Even if these sites are most often quite small, rescue excavations still give only punctual insights. Eschelbronn provides a rather unusual example, as the small castle is known in its entirety. Excavations made it possible to trace the development starting with settlement activities around 1190 from a wooden tower to a small castle built in stone during the $14^{\text {th }}$ century ${ }^{75}$. We know about different architectural types of rural castles like moated farmsteads, fortified towers and mottes, probably all present in the different phases of Eschelbronn. Their typical setting would be close to a church, in the periphery of the peasants' village and in alluvial meadows. They are quite different from classical castles, as they do not move to separated, hilltop situations visually dominating the landscape. For quite a long time, castellologists discussed mainly the practical military function of castles and pointed to their often rather symbolic meaning. In any case, the moated sites show a close contact between peasants and lords or at least their commissionaires (ministeriales).

In earlier rural settlements there are differences between types of house construction and the layout of farmsteads, possibly an indication for social differences within rural settlements. There are for example the rather large houses of the Irlbach type -however not comparable to the large houses of early medieval northern Europe ${ }^{76}$. Another example comes from Lauchheim, though not as might be supposed from the area of the so-called noble court ('Herrenhof') with a rich late Merovingian burial site. By now it is hardly

73 Zeune (2007).

74 Herrnbrodt (1958) -for the dating: Friedrich, Nobis (1998).

75 Mittelstraß (1997).

76 Schreg (2012a), p. 257. 
possible to identify Carolingian manor sites known from the written sources within the archaeological record ${ }^{77}$. Most sites that have been suggested as central places of the Carolingian to Salian period are fortified places which were probably rather important on a regional than at settlement level ${ }^{78}$. It is still an important task for medieval rural settlement archaeology to better understand the hierarchies of early medieval settlement systems. We need to verify whether the development of castles at hill sites was in fact a spatial movement and indicates the separation of noble families from the rural settlements. By now, the existence of manor sites in the villages is a rather late phenomenon and may in contrast indicate an increasing control of local societies by a nobility.

\section{LOCAL RURAL SOCIETIES}

As we have seen, the sources are biased in favour of the lords and the church who used writing for their administration or historiography. In principle, archaeological data has better chances to give peasants a voice. However, the traces of poor people are less visible and have often found little attention. Post holes, ceramic sherds and iron knives that make the majority of archaeological finds from rural settlements bear little information about the role of peasants within changing settlement systems. Until today it has been possible only in some extraordinary cases to establish social differences within medieval rural settlements. In general finds are too unspecific, excavation areas too small and sampling strategies for botanical and faunal remains and geochemical soil characteristics are not well established. Today most rescue excavations are not suited to preserve these latter sources of information, as currently research projects cannot manage large scale and long-term excavations due to science and heritage politics.

We know about remarkable social differences within the late medieval village in Southern Germany. In many villages lower classes played an important role. They normally did not have their own land but worked in rural handcrafts or as hired labourers. Some of these people are manifest in the village outline by their tiny houses, often characterizing whole streets or village quarters. But there were also large farmsteads, which obviously had some economic potential and wealth. Legally most farmers were integrated in complex feudal dependencies and were not free in their personal and economic decisions ${ }^{79}$.

In the early and high Middle Ages rural communities were probably not less complex, because there is a broad variety of terms for different social groups present in the written sources. We also learn of manorial systems, which left numerous documents and obviously dominated at least some settlements. But the documents provide an ideal picture, which is not valid for all peasants and does not reflect social practice within rural communities. There have been many attempts to correlate archaeological data with the

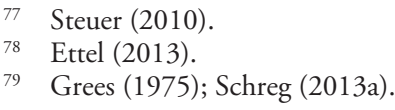


information from written sources, but they focus on the identification of manor sites, presuming that there was an ideal, specific settlement layout.

A promising approach may come from pottery studies. There is a remarkable change of ceramic wares in the $10^{\text {th }} / 11^{\text {th }}$ century, which supposedly reflects changing production and distribution systems related to changes within the feudal system. Wares produced in rather low quality using a slow, hand-driven turntable instead of a potter's wheel moved by pedals seem nevertheless to have been often repaired. This points to a situation when local pottery production gained in importance. As we can see in some cases through a correlation of the distribution of early wheel-turned wares with the distribution of estates of feudal complexes, pottery supply was probably provided by the feudal institution. The increasing significance of local production therefore could be an indication of more direct responsibilities of the individual farm economies ${ }^{80}$.

Understanding local rural societies therefore may not focus just on hierarchies but must deal with the village as a social arena ${ }^{81}$. Processes like the formation of the village, the introduction of the open field system or the late medieval crisis have many different aspects and certainly involved many people. The question of differences between lords and peasants is much too simple because we deal with a complex system including all people, as well as also economic, social and environmental factors.

\section{Conclusion}

In the light of this short review of four periods of change in the medieval rural landscape of Southern Germany, I want to briefly reflect upon the concept of 'agency'. In general, 'agency' is not defined very precisely as it is used in the context of different theoretical discourses mainly in the social sciences and in linguistics. Usually, 'agency' comprises the possibilities to act, as well as specific actions. It is linked to the questions of who takes action, how and with whom it is taken and what are the intentions and results.

In German archaeology the concept of agency has not been used very widely. The field of social archaeology developed only in recent years, and before this the focus was mainly on hierarchies. Even if theoretical considerations were well aware of the complexity of social structures and hierarchies, agency was not taken into consideration. In fact, the inference from archaeological finds to their initiator is not reliable. Agency is something rather abstract and as many other such concepts, as e.g. 'risk', 'habitus', or 'sustainability' it has not been used within German archaeology widely ${ }^{82}$.

Regarding the development of medieval cultural landscapes, we deal with long-term processes and thus we need to look rather for collective agents than for individuals. We may distinguish three or four spheres, to which an everyday peasant's 'agency' is directed: 1.) to the social sphere, 2.) to production and subsistence and 3.) to the environment. There is also a fourth section of 'agency', which refers to the religious sphere (fig. 5).

80 Schreg (2012b), pp. 10-13.

81 Comp. Dommasnes, Gutsmiedl-Schümann, Hommedal (2016).

82 Comp. Schreg (2017). 




FIGURE 5. Spheres of peasants'agency have different visibility in top-down and bottom-up perspectives (graphic: R. Schreg).

The social sphere is about interpersonal relationships. They are at the basis of local societies as well as of 'states' and institutions. However, social relations cannot be reduced to hierarchies and top-down relations. They must include the entire society and analyse power relations by looking at interests and daily life practices. It is important to look at relations of power in a Weberian definition and not based on the idea of 'dominance'.

In a Marxist perspective, modes of production are a prominent factor of historical processes and the agency of the lower classes is crucial for historical revolutions. Because economic activities are essential for survival, they are for sure an important historical driver. But it is a rather philosophical debate whether this agency belongs to individuals or collective working classes. For sure, not only traders, industrialists, politicians, and rulers have economic interests.

Modern environmentalism made us aware of the important role individuals can play in different ways. Individuals are economic factors, but they also contribute to social 
value systems. Even if people do not take initiative, they have their own agency that may be decisive about the success of change processes.

Environmental history taught us about 'glocalism' (the local in the global), "the simultaneity -the co-presence- of both universalizing and particularizing tendencies» ${ }^{83}$ which means that local or individual activities in modern times often have global effects $^{84}$.

Initiatives or an active agency may have unintended effects as nobody understands all interconnections. Important effects may also come from economic activities below the scope of politics.

Agency is the potential of people to influence historical processes. This includes individual, intended action as well as accustomed behaviour. Intentional, and effective action are not mandatory criteria of agency. Daily work is part of an agency, in general targeted to satisfy needs.

According to our modern ideas, religious rites or symbolic actions do not have reasonable effects, but we cannot exclude them from a definition of agency. Quite often the unintended effects of behaviour or agency become historical drivers. Unintended effects are often of great importance in the context of ecological systems and processes of environmental history.

But agency is also a question of power. Whereas traditional views looked at power relations from an institutional point of view and reduced it to forms of military or economic dominance, it's more useful to use the Weberian definition. Max Weber understood power as all means to motivate others to fulfil their will. This includes a broad range of social practices far beyond formal hierarchies.

This broadly defined 'agency' and power is reflected in the written and material sources only in few small sections.

This paper asked for the agency of people behind processes of medieval settlement history. The examples from Southern Germany showed, how agency was part of modern-day ideologies and how it influenced modern interpretations. It is my hypothesis, that these processes can not be understood by looking at formal institutions. We instead need a perspective coming from human ecology, which takes societies as part of a wider and more complex ecosystem that is characterized by manifold interconnections. In order to understand long-term processes, we need a broad definition of agency, which in itself has little explanatory value, but may trigger deeper research.

\section{REFERENCES}

Abel, W., 1955. Die Wüstungen des ausgehenden Mittelalters. 2 Aufl. Stuttgart: Gustav Fischer. Quellen und Forschungen zur Agrargeschichte. 1.

Althoff, G., 2003. Inszenierte Herrschaft. Geschichtsschreibung und politisches Handeln im Mittelalter. Darmstadt: WBG.

83 Robertson (1997).

84 Radkau (2002). 
Althoff, G., 2012. Die Macht der Rituale. Symbolik und Herrschaft im Mittelalter. 2. Aufl. Darmstadt: WBG.

Andrén, A., 1998. Between artifacts and texts. Historical archaeology in global perspective. New York: Plenum Press. Contributions to global Historical Archaeology.

BADER, K. S., 1941. Bauernrecht und Bauernfreiheit im späteren Mittelalter. Historisches Jahrbuch, 61, pp. 51-87.

Bader, K. S., 1957. Das mittelalterliche Dorf als Friedens- und Rechtsbereich. Weimar: Böhlau. Studien zur Rechtsgeschichte des mittelalterlichen Dorfes. 1.

BäNTELI, K., 2000. Berslingen - verschwunden und wiederentdeckt: Braune Flecken als letzte Zeugen. In: K. Bänteli, M. Höneisen, and K. Zubler, eds. Berslingen - ein verschwundenes Dorf bei Schaffhausen. Mittelalterliche Besiedlung und Eisenverhüttung im Durachtal. Schaffhausen: Baudepartement des Kantons Schaffhausen Kantonsarchäologie, pp. 53-82.

Bauch, M. and G. J. Schenk, eds., 2019. The Crisis of the 14th Century. Berlin, Boston: de Gruyter. Das Mittelalter. Beih. 13.

Beck, R., 2004. Unterfinning. Ländliche Welt vor Anbruch der Moderne. 1. Aufl. München: C. H. Beck.

Bernhard, H., 1982. Die frühmittelalterliche Siedlung Speyer 'Vogelgesang'. Offa. Berichte und Mitteilungen zur Urgeschichte, Frühgeschichte und Mittelalterarchäologie, 39, pp. 217-233.

Biermann, F., 2010. Archäologische Studien zum Dorf der Ostsiedlungszeit. Die Wüstungen Miltendorf und Damsdorf in Brandenburg und das ländliche Siedlungswesen des 12. bis 15. Jahrhunderts in Ostmitteleuropa. Zossen: Brandenburgisches Landesamt für Denkmalpflege und Archäologisches Landesmuseum. Forschungen zur Archäologie im Land Brandenburg. 12.

Blickle, P., 2000. Kommunalismus Skizzen einer gesellschaftlichen Organisationsform. Band 1: Oberdeutschland. München: Oldenbourg.

BoIs, G., 1999. Umbruch im Jahr 1000. Lournand bei Cluny - ein Dorf in Frankreich zwischen Spätantike und Feudalherrschaft. München: Deutscher Taschenbuch-Verlag.

Bourin, M. 2004. Pour une anthropologie du prélèvement seigneurial dans les campagnes médiévales $\left(X I^{e}-X I V^{e}\right.$ siècles). Réalités et représentations paysannes. Paris: Publ. de la Sorbonne. Histoire ancienne et medievale, 68.

Bork, H.-R., A. Beyer, and A. Kranz, 2011. Der 1000-jährige Niederschlag des Jahres 1342 und seine Folgen in Mitteleuropa. In: F. Daim, D. Gronenborn, and R. Schreg, eds. Strategien zum Überleben. Umweltkrisen und ihre Bewältigung. Mainz: Verlag des RömischGermanischen Zentralmuseums, pp. 231-242.

Dommasnes, L. H., D. Gutsmiedl-Schümann, and A. T. Hommedal, eds., 2016. The farm as a social arena. Münster: Waxmann.

Donat, P., 1980. Haus, Hof und Dorf in Mitteleuropa vom 7. bis 12. Jahrhundert. Archäologische Beiträge zur Entwicklung und Struktur der bäuerlichen Siedlung. Berlin: Akademie-Verlag. Schriften zur Ur- und Frühgeschichte. 33.

Ebersbach, R., 2010. Vom Entstehen und Vergehen - Überlegungen zur Dynamik von Feuchtbodenhäusern und -siedlungen. In: I. Matuschiк and C. Strahm, eds. Vernetzungen. Aspekte siedlungsarchäologischer Forschung. Festschrift für Helmut Schlichtherle zum 60. Geburtstag. Freiburg im Breisgau: Lavori-Verlag, pp. 41-50.

Eтtel, P., 2013. Zentralorte und Zentralräume des Frühmittelalters in Süddeutschland. ein Forschungsüberblick. In: P. EtTel and L. Werther, eds. Zentrale Orte und zentrale Räume des Frühmittelalters in Süddeutschland. Mainz: Schnell \& Steiner; Verlag des Römisch-Germanischen Zentralmuseums, pp. 1-46. 
FeHRING, G. P., 1973. Zur archäologischen Erforschung mittelalterlicher Dorfsiedlungen in Südwestdeutschland. Zeitschrift für Agrargeschichte und Agrarsoziologie, 21, pp. 1-35.

Fehring, G. P., 1987. Einführung in die Archäologie des Mittelalters. Darmstadt: WBG (Wiss. Buchges.).

Gentili, F., A. Lefèvre, eds., 2009, L’habitat rural du haut Moyen Âge en Île-de-France. Suppl. au Bulletin archéologique du Vexin francais 2. Guiry-en-Vexin.

Friedrich, R. and G. Nobis, 1998. Mittelalterliche Keramik aus rheinischen Motten. Funde aus den Regierungsbezirken Köln und Düsseldorf. Köln: Rheinland-Verlag. Rheinische Ausgrabungen. 44.

Fuchs, Chr., 2019. Marxism. Karl Marx's Fifteen Key Concepts for Cultural and Communication Studies. Milton: Taylor \& Francis Group.

GreEs, H., 1975. Ländliche Unterschichten und ländliche Siedlung in Ostschwaben. Tübingen: Geographisches Institut der Universität Tübingen. Tübinger geographische Studien. 58.

Gringmuth-Dallmer, E., 1983. Die Entwicklung der frühgeschichtlichen Kulturlandschaft auf dem Territorium der DDR unter besonderer Berücksichtigung der Siedlungsgebiete. Berlin. Schriften zur Ur- und Frühgeschichte. 35.

Grunwald, L. and R. Schreg, 2013. Frühmittelalterliche Siedlungen und Gräberfelder in der Gemarkung von Neuwied-Gladbach. Archäologisches Korrespondenzblatt, 43(4), pp. 569585.

Hamerow, H. 2002. Early Medieval Settlements. The Archaeology of Rural Communities in NorthWest Europe 400-900. Oxford: Oxford University Press.

Herget, J. and E. Zisnden, 2017. Der meteorologische Super-GAU. Die Magdalenenflut vom Juli 1342 und ihre Folgen. Geographische Rundschau, 69(9), pp. 40-48.

Herrnbrodt, A., 1958. Der Husterknupp. eine rheinische Burganlage des frühen Mittelalters. Köln.

Hildebrandt, H., 1980. Studien zum Zelgenproblem. Untersuchungen über flürlichen Anbau aufgrund methodenkritischer Interpretationen agrargeschichtlicher Quellen aus dem deutschsprachigen Raum. Mainz. Mainzer geographische Studien. 14.

Hinz, H., 1967. Die Stellung der Curtes innerhalb des karolingischen Wehrbaus. Germania, 45, pp. $130-142$.

Holst, M. K., 2010. Inconstancy and stability - Large and small farmsteads in the village of Nørre Snede (Central Jutland) in the first millennium AD. Siedlungs- und Küstenforschung im südlichen Nordseegebiet 33, pp. 155-179.

Iversen, T., J. R. Myking, St. Sonderegger, 2020. Peasants, Lords, and State. Boston: Brill. The Northern World Series 89.

Janssen, W., 1968. Mittelalterliche Dorfsiedlungen als archäologisches Problem. Frühmittelalterliche Studien, 2, 305-367.

Koнl, T., 2010. Lokale Gesellschaften. Formen der Gemeinschaft in Bayern vom 8. bis zum 10. Jahrhundert. Stuttgart: Thorbecke. Mittelalter-Forschungen. 29.

Kossack, G., 1988. Ortsnamen und Wohnplatzmobilität. In: V. Setschkareff, P. Rehder, and H. Schmid, eds. Ars Philologica. Festschrift H. Kunstmann. München, $254 \mathrm{ff}$.

Kossinna, G., 1911. Die Herkunft der Germanen. Zur Methode der Siedlungsarchäologie. Würzburg: Curt Kabitsch. Mannus-Bibliothek. 6.

LARrEA, J.-J., 2019. Escribir el espacio entre la auctoritas, la lengua hablada y el régimen agrario. Campus en los fondos documentales de Wissembourg, Lorsch y Fulda entre el siglo virI y mediados del Ix [online]. Studia Historica. Historia Medieval, 37(1), 53. Available from: $10.14201 /$ shhme20193715378 
Loveluck, Ch. 2013. Northwest Europe in the early Middle Ages, c. AD 600-1150. A comparative archaeology. Cambridge: Cambridge University Press.

Lund, A., 1970. On the Meaning of a Much Discussed Passage in the Germania of Tacitus (26,12). Classica et Mediaevalia, 31, pp. 124-129.

Meyer, W., 1979. Rodung, Burg und Herrschaft. Ein burgenkundlicher Beitrag zur mittelalterlichen Siedlungsgeschichte. In: W. MeYer, ed. Burgen aus Holz und Stein. Burgenkundl. Koll. Basel 1977. Olten, pp. 43-80.

Mittelstrass, T., 1997. Eschelbronn. Entstehung, Entwicklung und Ende eines Niederadelssitzes im Kraichgau (12. - 18. Jh.). Stuttgart. Forschungen und Berichte der Archäologie des Mittelalters in Baden-Württemberg. 17.

MüLler, M., 2004. Auswirkungen von Änderungen der Landnutzung auf das lokale Klima in Räumen mit unterschiedlichem Relief. Der nächtliche Strahlungshaushalt historischer Landnutzungsmuster im Bereich südlicher Oberrhein, Schwarzwald und Baar. Freiburg.

NitZ, H.-J., 1974. Regelmäßige Langstreifenfluren und fränkische Staatskolonisation. Eine Untersuchung ihrer Zusammenhänge im westlichen Oberrheingebiet und anderen deutschen Landschaften. In: H.-J. Nitz, ed. Historisch-genetische Siedlungsforschung. Genese und Typen ländlicher Siedlungen und Flurformen. Darmstadt, pp. 334-360.

Oexle, O. G. and J. Rüsen, 1996. Historismus in den Kulturwissenschaften. Geschichtskonzepte, historische Einschätzungen, Grundprobleme. Köln,Böhlau. Beiträge zur Geschichtskultur 12.

Paret, O., 1937. Die frühschwäbischen Gräberfelder von Gross-Stuttgart und ihre Zeit. Stuttgart: Krais. Veröffentlichungen des Archivs der Stadt Stuttgart. 2.

Radkau, J., 2002. Natur und Macht. Eine Weltgeschichte der Umwelt. München: C. H. Beck.

Robertson, R., 1997. Comments on the "Global Triad» and «Glocalization». In: N. Inoue, ed. Globalization and indigenous culture. Tokyo, Japan: Institute for Japanese Culture and Classics Kokugakuin University.

RöSENER, W., ed., 2000. Kommunikation in der ländlichen Gesellschaft vom Mittelalter bis zur Moderne. Göttingen: Vandenhoeck \& Rupprecht. Veröffentlichungen des Max-Planck-Instituts für Geschichte 156.

Schiffer, M. B., 1987. Formation process of the archaeological record. Salt Lake City.

Schlüter, O., 1952. Die Siedlungsräume Mitteleuropas in frühgeschichtlicher Zeit. 1. Einführung in die Methodik der Altlandschaftsforschung. Remagen. Forschungen zur deutschen Landeskunde. 63.

SchöttleR, P., 1994. Zur Geschichte der Annales-Rezeption in Deutschland (West). In: M. Middell, ed. Alles Gewordene hat Geschichte: die Schule der Annales in ihren Texten 19291992. Leipzig: Reclam, pp. 40-60.

Schreg, R., 2006. Dorfgenese in Südwestdeutschland. Das Renninger Becken im Mittelalter. Stuttgart: Konrad Theiss Verlag. Materialhefte zur Archäologie in Baden-Württemberg. 76.

Schreg, R., 2008. Before Colonization: Early Medieval Land-Use of Mountainous Regions in Southern and Western Germany. In: C. Bartels and C. Küpper-Eichas, eds. Cultural Heritage and Landscapes in Europe - Landschaften - kulturelles Erbe in Europa. Bochum, pp. 293-312.

Schreg, R., 2012a. Farmsteads in early medieval Germany - architecture and organisation. $A r-$ queología de la Arquitectura, 9, pp. 247-265.

Schreg, R., 2012b. Keramik des 9. bis 12. Jahrhunderts am Rhein. Forschungsperspektiven auf Produktion und Alltag. In: H. Pantermenl, L. Grunwald, and R. Schreg, eds. Hochmittelalterliche Keramik am Rhein. Eine Quelle für Produktion und Alltag des 9. bis 12. Jahrhunderts. Mainz, pp. 1-19. 
Schreg, R., 2012c. Kontinuität und Fluktuation in früh- und hochmittelalterlichen Siedlungen. In: C. Fey and S. Krieb, eds. Adel und Bauern in der Gesellschaft des Mittelalters. Internationales Kolloquium zum 65. Geburtstag von Werner Rösener. Korb: Didymos-Verlag, pp. 137-164.

Schreg, R., 2013a. Commons, cooperatives and village communes - geographical and archaeological perspectives on the role of rural lower classes in settlement restructuring at the Swabian Alb plateau. In: J. KLÁPŠTĚ, ed. Hierarchies in rural settlements. Ruralia VII. Turnhout: Brepols, pp. 101-121.

Schreg, R., 2013b. Würzbach - ein Waldhufendorf im Nordschwarzwald. In: C. Theune-Vogt, G. Scharrer-Liška, E.H. Huber, and T. Kühtreiber, eds. Stadt - Land - Burg. Festschrift für Sabine Felgenhauer-Schmiedt zum 70. Geburtstag. Rahden/Westf.: VML Verlag Marie Leidorf, pp. 189-202.

Schreg, R., 2014a. Ecological approaches in medieval rural archaeology [online]. European Journal of Archaeology, 17(1), 83-119. Available from: 10.1179/1461957113Y.0000000045

Schreg, R., 2014b. Uncultivated landscapes or wilderness? Early medieval land use in low mountain ranges and flood plains of Southern Germany. European Journal of Post-Classical Archaeologies, 4, pp. 69-98.

Schreg, R., 2016a. Mittelalterliche Feldstrukturen in deutschen Mittelgebirgslandschaften Forschungsfragen, Methoden und Herausforderungen für Archäologie und Geographie. In: J. KLÁPŠTĚ, ed. Agrarian technology in the medieval landscape. Ruralia X. Turnhout: Brepols, pp. 351-370.

Schreg, R., 2016b. Quellenkritik. In: B. Scholkmann, H. Kenzler, and R. Schreg, eds. Archäologie des Mittelalters und der Neuzeit. Grundwissen. Darmstadt: WBG, pp. 101-112.

Schreg, R., 2016c. Quelleninterpretation und Theorie. In: B. Scholkmann, H. Kenzler, and R. Schreg, eds. Archäologie des Mittelalters und der Neuzeit. Grundwissen. Darmstadt: WBG, pp. 116-127.

Schreg, R., 2016d. Sozialarchäologie. In: B. Scholkmann, H. Kenzler, and R. Schreg, eds. Archäologie des Mittelalters und der Neuzeit. Grundwissen. Darmstadt: WBG, pp. 254-263.

Schreg, R., 2017. Interaktion und Kommunikation im Raum - Methoden und Modelle der Sozialarchäologie. In: S. Brather and J. Dendorfer, eds. Grenzen, Räume und Identitäten. Der Oberrhein und seine Nachbarregionen von der Antike bis zum Hochmittelalter. Ostfildern: Jan Thorbecke Verlag, pp. 455-492.

Schreg, R., 2018a. Mönche als Pioniere in der Wildnis? Aspekte des mittelalterlichen Landesausbaus. In: M. Krätschmer, K. Thode, and C. Vossler-Wolf, eds. Klöster und ihre Ressourcen. Räume und Reformen monastischer Gemeinschaften im Mittelalter. Tübingen, pp. 39-58.

Schreg, R., 2018b. Rinder und Schafe - Akteure mittelalterlicher Umweltgeschichte. In: T. PomMerening and J. Althoff, eds. Kult, Kunst, Konsum - Tiere in alten Kulturen. Darmstadt: Philipp von Zabern, pp. 72-89.

Schreg, R., 2019a. Assessing Settlement Dynamics in Medieval Central and Western Europe. In: M.S. Popović, V. Polloczer, B. Koschicek, and S. Eichert, eds. Power in landscape. Geographic and digital approaches on historical research. Leipzig: Eudora, pp. 227-244.

SCHREG, R., 2019b. Late medieval deserted settlements in Southern Germany as a consequence of long-term landscape transformations. In: N. Brady and C. Theune, eds. Settlement Change across Medieval Europe. Old Paradigms and new vistas. Ruralia XIII Kilkenny 2017. Leiden: Sidestone Press, pp. 161-170.

Schreg, R., 2020. Human Impact on Hydrology Direct and Indirect Consequences of Medieval Urbanisation in Southern Germany. In: N. Chiarenza, A. Haug, and U. Müller, eds. The Power of Urban Water. Studies in premodern urbanism. [S.1.]: de Gruyter, pp. 249-264. 
Schreg, R. 2020a. Vergessene Pioniere der Mittelalterarchäologie: Das RGZM in der Weimarer Republik. Archaeologik 15.6.2020. Available from https://archaeologik.blogspot. com/2020/06/vergessene-pioniere-der.html

Schröder, M., 1997. Freilichtmuseen in Baden-Württemberg. Entstehung, Entwicklung, Wirkung. Tübingen. Untersuchungen des Ludwig-Uhland-Instituts der Universität Tübingen 86.

Schröder-Lembke, G., 1978. Studien zur Agrargeschichte. Stuttgart: Fischer. Quellen und Forschungen zur Agrargeschichte. 31.

Schumacher, K., 1925. Siedlungs- und Kulturgeschichte der Rheinlande von der Urzeit bis ins Mittelalter. Die merowingische und karolingische Zeit. Mainz. Handb. RGZM. 1/3.

Spazier, I., 2005. Die Genese hoch- und spätmittelalterlicher Dörfer in der Niederlausitz. In: F. Biermann and G. Mangelsdorf, eds. Die bäuerliche Ostsiedlung des Mittelalters in Nordostdeutschland. Untersuchungen zum Landesausbau des 12. bis 14. Jahrhunderts im ländlichen Raum. Frankfurt am Main: Lang Europ. Verl. der Wiss., pp. 255-268.

SPEK, T. 2006. Entstehung und Entwicklung historischer Ackerkomplexe und Plaggenböden in den Eschlandschaften der nordöstlichen Niederlande (Provinz Drenthe). In: Siedlungsforschung. 24, pp. 219-250.

Spengler, O., 1923. Der Untergang des Abendlandes. München: C.H. Beck.

Steuer, H., 1988. Standortverschiebungen früher Siedlungen - von der vorrömischen Eisenzeit bis zum frühen Mittelalter. In: G. Althoff, D. Geuenich, O. G. Oexle, and J. Wollasch, eds. Person und Gemeinschaft im Mittelalter. Festschr. K. Schmid. Sigmaringen, pp. 25-59.

Steuer, H., 2010. Herrensitze im merowingerzeitlichen Süddeutschland. Herrenhöfe und reich ausgestattete Gräber. Zeitschrift für Archäologie des Mittelalters, 38, pp. 1-41.

Stoll, H., 1939. Die Alamannengräber von Hailfingen in Württemberg. Berlin. Germanische Denkmäler der Völkerwanderungszeit. 4.

Thode, K., 2015. Terrassen, mächtige Mauern und ein rätselhafter Rundbau - Grabungen in der Wüstung Oberwürzbach 2015. Archäologische Ausgrabungen in Baden-Württemberg, pp. 229-232.

Veeck, W., 1931. Die Alamannen in Württemberg. Berlin: Walter de Gruyter. Germanische Denkmäler der Völkerwanderungszeit. 1.

Waterbolk, H. T., 1973. Odoorn im frühen Mittelalter. Bericht der Grabung 1966. Neue Ausgrabungen und Forschungen in Niedersachsen, 8, pp. 25-89.

Weller, K., 1937. Die freien Bauern des Spätmittelalters im heutigen Württemberg. Zeitschrift für Württembergische Landesgeschichte, 1, pp. 47-67.

Weller, K., 1938. Besiedlungsgeschichte Württembergs vom 3. bis 13. Jahrhundert n. Chr. Stuttgart: Kohlhammer. Besiedlungsgeschichte Württembergs 3.

White, L. jun., 1962. Medieval technology and Social Change. Oxford.

White, L., jun., 1968. Die mittelalterliche Technik und der Wandel der Gesellschaft. München: Moos.

Zadora-Rio, E., 1996. Le village des historiens et le village des archéologues. In: E. Mornet, ed. Campagnes médiévales: L'homme et son espace. Paris, pp. 145-153.

Zeune, J., 2007. Zum Stand der Motten-Forschung in Bayern und Baden-Württemberg. In: S. Felgenhauer-Schmiedt, A. Eibner, and P. Csendes, eds. Motte - Turmbügelburg - Hausberg. Zum europäischen Forschungsstand eines mittelalterlichen Burgentypus. Wien: Österr. Gesellschaft für Mittelalterarchäologie, pp. 155-162. 